Maurer School of Law: Indiana University

Digital Repository @ Maurer Law

$10-2014$

\title{
Learning from Conservation Planning for the U.S. National Wildlife Refuges
}

Robert L. Fischman

Indiana University Maurer School of Law, rfischma@indiana.edu

Vicky J. Meretsky

Indiana University O'Neill School of Public and Environmental Affairs

Follow this and additional works at: https://www.repository.law.indiana.edu/facpub

Part of the Biology Commons, Environmental Law Commons, Natural Resources and Conservation Commons, and the Natural Resources Management and Policy Commons

\section{Recommended Citation}

Fischman, Robert L. and Meretsky, Vicky J., "Learning from Conservation Planning for the U.S. National Wildlife Refuges" (2014). Articles by Maurer Faculty. 2993.

https://www.repository.law.indiana.edu/facpub/2993

This Article is brought to you for free and open access by the Faculty Scholarship at Digital Repository @ Maurer Law. It has been accepted for inclusion in Articles by Maurer Faculty by an authorized administrator of Digital Repository @ Maurer Law. For more information, please contact rvaughan@indiana.edu. 


\title{
Learning from Conservation Planning for the U.S. National Wildlife Refuges
}

\author{
VICKY J. MERETSKY* AND ROBERT L. FISCHMAN† \\ ${ }^{*}$ School of Public and Environmental Affairs, 1315 East Tenth St., SPEA 430, Indiana University, Bloomington, IN, 47405, U.S.A, \\ email meretsky@indiana.edu \\ †Maurer School of Law, Indiana University Maurer School of Law, 211 S. Indiana Ave., Bloomington, IN 47405, U.S.A
}

\begin{abstract}
The U.S. National Wildlife Refuge System bas nearly completed its first round of unit-level, comprebensive conservation plans (CCPs) and will soon begin required revisions. Laws and policies governing refuge planning emphasize ecological integrity, landscape-scale conservation, and adaptive management. We evaluated 185 CCPs completed during 2005-2011, which cover 324 of 555 national wildife refuges. We reviewed CCP prescriptions addressing 5 common conservation issues habitat and game, nongame, imperiled, and invasive species) and 3 specialized topics (landscape-scale conservation, climate change, and environmental quality). Common conservation issues received prescriptions in $>90 \%$ of CCPs. Specialized topics received more variable treatment. Prescriptions for aquatic connectivity, water quantity, and climatechange impacts increased over the study period. Except for climate change, direct actions were the most common type of management prescription, followed by plans or studies. Most CCPs stated a commitment to adaptive management and prescribed monitoring for common conservation objectives; other aspects of planning for adaptive management were often lacking, despite strong support for adaptive management in the conservation planning literature. To better address refuge-specific threats, we recommend that revised plans explicitly match identified refuge issues with prescriptions, particularly for under-represented concerns such as novel pests and pathogens. We recommend incorporating triggers into monitoring frameworks and specifying actions that will occur when threshold values are reached to improve support for adaptive management. Revised CCPs should better reflect work that refuges already undertake to extend conservation objectives beyond their borders and better engage with regional conservation efforts to continue this work. More thorough landscape-scale threat assessments and explicit prioritization of planned actions would further improve conservation effectiveness. Excellent examples of all recommended practices exist within the CCPs we examined; sharing best planning practices would improve planning efficiency within the refuge system.
\end{abstract}

Keywords: adaptive management, conservation planning, protected areas, public land management, wildlife refuge

Aprendiendo de la Planeación de la Conservación para los Refugios Nacionales de Vida Silvestre de EUA

Resumen: El Sistema Nacional de Refugios de Vida Silvestre de EUA casi ha completado su primera ronda de nivel unidad, planes de conservación comprensivos (CCPs en inglés) y pronto comenzará con las revisiones requeridas. Las leyes y políticas que gobiernan la planeación de refugios enfatizan la integridad ecologica, la conservación a escala de terreno y el manejo adaptativo. Evaluamos 185 CCPs completados entre 2005 - 2011 , los que cubren 324 de 555 refugios nacionales de vida silvestre. Revisamos las prescripciones de los CCPs que se dirigen a 5 cuestiones comunes en la conservación (bábitat y caza, especies de ningún interés para la caza, en peligro e invasoras). Las cuestiones comunes de conservación recibieron prescripciones en $>90 \%$ de los CCPs. Los temas especializados recibieron mayor tratamiento variable. Las prescripciones para la conectividad acuática, la cantidad de agua y los impactos del cambio climático incrementaron a lo largo del periodo de estudio. CA excepción del cambio climático, las acciones directas fueron el tipo más común de prescripción de manejo, seguido por los planes o los estudios. La mayoría de los CCPs declararon un compromiso al manejo adaptativo y prescribieron el monitoreo para los objetivos comunes de conservación; otros aspectos de la planeación para el manejo adaptativo frecuentemente estuvieron ausentes, a pesar del fuerte apoyo

Paper submitted June 14, 2013; revised manuscript accepted January 4, 2014. 
para el manejo adaptativo en la literatura de la planeación de la conservación. Para dirigirse mejor a las amenazas específicas de refugio, recomendamos que los planes revisados igualen explícitamente las cuestiones identificadas de refugio con prescripciones, particularmente para preocupaciones sub-representadas como plagas y patógenos novedosos. Recomendamos incorporar disparadores a los marcos de trabajo del monitoreo y especificar acciones que ocurrirán cuando los valores de los umbrales se alcancen para mejorar el apoyo al manejo adaptativo. Las CCPs revisadas deberían reflejar mejor el trabajo que los refugios ya emprenden para extender los esfuerzos de conservación para continuar esta labor. Estudios de amenaza a escala de terreno más extensivos y la priorización explícita de las acciones planeadas mejoraría más la efectividad de la conservación. Existen excelentes ejemplos de todas las prácticas recomendadas dentro de los CCPs que examinamos; compartir las mejores prácticas de planeación mejoraría la eficiencia de la planeación dentro del sistema de refugios.

Palabras Clave: àreas protegidas, manejo adaptativo, manejo de terrenos públicos, planeación de la conservación, refugio de vida silvestre

\section{Introduction}

Conservation planners have an increasingly sophisticated toolbox with which to assess threats, manage reserves, and design reserve networks. In the United States, legislation requires agencies managing national forests, national wildlife refuges, and national parks to prepare individual, unit-level management plans for their lands. In most circumstances, plans are legally binding on resource management agencies. Yet, very little empirical research (Bottrill \& Pressey 2012) has examined these plans.

The national wildlife refuges, managed by the U.S. Fish and Wildlife Service (FWS), were the last federal conservation lands to receive a congressional mandate for planning. The FWS is finishing its initial land-management plans, called comprehensive conservation plans (CCPs), and preparing for the first round of revisions (USFWS 2011). First-generation CCPs reveal how refuge management has responded to legal, policy, and conservation reforms of the past 15 years. Among the changes most relevant to biodiversity conservation are a broadening of focus from migratory birds and game species to ecological integrity of the refuge and surrounding landscape; a shift from addressing conservation through actions within refuge boundaries to a more collaborative approach that seeks partners in a wider conservation landscape; and increased attention to monitoring within the framework of adaptive management (Fischman 2003).

We offer the first comprehensive account of the CCPs. We compared the language of the plans with guidance in FWS policy and with the broader standards for conservation planning (Hilty \& Groves 2009). We concentrated on prescriptions (courses of action or study) because, more than any other components, they drive management (Loomis 2002). An FWS handbook (Adamcik et al. 2004) establishes 5 SMART criteria for effective prescriptions: they should be specific, measurable, achievable, results oriented, and time fixed. Because the mere existence of a prescription tells one little about how effectively it may be implemented, we also assessed content of prescriptions to better understand how well they translate into actual refuge management.
The lessons learned from our examination of existing CCPs are applicable directly to CCP revisions and, broadly, to other conservation planning efforts. In particular, the U.S. Forest Service recently established a new framework to guide its 15-year land and resource management plans ( 77 Fed. Reg. 21,162 (2012)) and state wildlife agencies are in the early stages of their first 10year revision of state wildlife action plans (SWAPs).

\section{Methods}

In partnership with FWS, the authors and 25 graduate students examined the CCPs finalized between 2005 and 2012. For each CCP, we recorded information on a wide range of attributes but concentrated on biological goals, objectives, and implementation strategies of the CCPs, which we refer to collectively as prescriptions.

We determined whether CCPs did not mention, mentioned as a general or regional concern, or mentioned as a refuge concern 5 common conservation issues (habitat and game, nongame, federally listed, and invasive species). Provisions addressing taxa that encompass game and nongame species (e.g., mammals) were assumed to include both; in contrast, provisions were only coded as addressing federally listed species if they did so explicitly. We used the same coding for 3 specialized topics: landscape conservation ( 4 aspects), climate change (9 aspects), and environmental quality ( 4 aspects). For each of these 22 issues, plus an additional 9 issues related primarily to land use (e.g., development impacts, agricultural impacts, inholdings), we determined whether CCPs contained responsive prescriptions.

When CCPs addressed common or specialized (but not land-use) refuge issues in prescriptions, we evaluated how prescriptions used 4 major planning approaches (study or plan, actions on a refuge, modeling, actions outside a refuge) and how they addressed 4 aspects of adaptive management (monitoring, specific action following from monitoring, use of monitoring targets, and whether monitoring targets were qualitative or quantitative). Actions outside the refuge included on-the-ground 
Table 1. Distribution of comprehensive conservation plans for which planning prescriptions were evaluated broken down by year of completion of the plan and U.S. Fish and Wildlife Service region in which refuges covered by the plan are located.

\begin{tabular}{|c|c|c|c|c|c|c|c|c|c|c|}
\hline \multirow[b]{2}{*}{ U.S. region } & \multicolumn{7}{|c|}{ Year } & \multirow[b]{2}{*}{ Total } & \multirow{2}{*}{$\begin{array}{l}\text { Total refuges } \\
\text { in CCPs }\end{array}$} & \multirow{2}{*}{$\begin{array}{l}\text { Refuges in } \\
\text { region (\%) }\end{array}$} \\
\hline & 2005 & 2006 & 2007 & 2008 & 2009 & 2010 & 2011 & & & \\
\hline Pacific Northwest \& Pacific islands & 1 & 0 & 3 & 5 & 2 & 5 & 8 & 24 & 36 & 53.0 \\
\hline Southwest & 0 & 4 & 0 & 1 & 1 & 3 & 0 & 9 & 13 & 28.9 \\
\hline Midwest & 4 & 2 & 4 & 2 & 2 & 2 & 1 & 17 & 22 & 40.7 \\
\hline Southeast and Caribbean islands & 4 & 19 & 10 & 15 & 11 & 12 & 4 & 75 & 105 & 82.0 \\
\hline Northeast & 4 & 4 & 2 & 1 & 3 & 4 & 4 & 22 & 37 & 51.4 \\
\hline Mountain prairie & 2 & 4 & 5 & 3 & 1 & 0 & 1 & 16 & 80 & 64.5 \\
\hline Alaska & 0 & 1 & 0 & 4 & 2 & 1 & 1 & 9 & 11 & 68.8 \\
\hline Southwestern Pacific & 1 & 3 & 1 & 0 & 5 & 2 & 1 & 13 & 20 & 40.0 \\
\hline Total & 16 & 37 & 25 & 31 & 27 & 29 & 20 & 185 & 324 & 555 \\
\hline
\end{tabular}

work such as assisting with riparian buffer planting, participation in community events (e.g., town meetings), and educational work designed to affect activities outside the refuge. Qualitative targets included such terms as increase, decrease, and maintain. Quantitative targets included directions such as increase by $5 \%$, double, and maintain densities at or below 2 bears per square mile. If both qualitative and quantitative targets were used, quantitative targets were coded.

We assessed use of planning approaches and adaptive management for landscape conservation, climate change, and environmental quality at the broad level, rather than at the aspect level. There were 8 assessments in total: 5 common topics and 3 specialized topics. To qualify as a specific intention to act on monitoring results, a prescription had to provide more than a rationale for monitoring.

\section{Validating Data Quality}

Prior to data collection, the authors compared their codings of 4 different CCPs to standardize scoring practices. To reduce variability, the authors and students scored one CCP together in class and shared answers to difficult scoring issues on a wiki-style Web site. We cross-checked 24 CCPs (one from each student) to assess scoring consistency. We eliminated variables with inconsistent differences among scorers. Cross-checking showed that, for the more difficult questions involving management approaches and adaptive management, student errors consistently under-represented use of management approaches and adaptive management. Thus, our results tended to under-report CCP attributes in these areas.

\section{Results}

We evaluated all CCPs completed during 2005-2011, except 4 that covered only wetland management districts. The 185 CCPs from this period represented planning for
324 of 555 national wildlife refuges extant in 2012 (58\%; Table 1). Of 185 CCPs, 139 were single-refuge CCPs; the remaining 46 covered multiple refuges. The CCPs generally listed $3-12$ broad goals $(\max =24)$, but only $17.3 \%$ explicitly prioritized goals.

\section{Management Issues and Prescriptions}

The majority of CCPs included prescriptions that addressed the 5 common conservation topics; treatment of specialized topics was more variable (Table 2 ). The landscape-conservation group had the highest average proportion of prescriptions, but the environmentalquality group had the single topic with the highest proportion of prescriptions (water quality). No single climate-change issue addressed in prescriptions appeared in $>32 \%$ of CCPs.

Trends over time in proportion of CCPs with prescriptive language varied considerably among the topics we examined. Common refuge topics of concern were consistently addressed by $>70 \%$ of CCPs throughout 2005-2011. Among the landscape topics, prescriptions increased most for aquatic connectivity (Table 3). Proportions of CCPs that addressed climate-change threats tended to increase over time in all 10 recorded aspects of climate change, at least through 2010 (elsewhere, we report in greater detail on climate-change aspects of CCPs). Increases were largest for climate-change impacts to habitat and plant communities. Responses to change in fire frequency and intensity and to potential increases in diseases and parasites were least evident. Among the environmental-quality topics, water quality and quantity were more often addressed through prescriptions, and both increased irregularly over time. In contrast, prescriptions for air quality and noise pollution did not increase over time.

Among the 9 land-use topics, 6 (existing development, agriculture, future development, on-refuge recreation, dams, and roads) were discussed in the majority of CCPs, but none appeared in prescriptions in the majority of CCPs. For instance, discussion of threats from future 
Table 2. Proportions of comprehensive conservation plans (CCPs) that address common and specialized conservation topics broken down by level of concern and treatment. ${ }^{a}$

\begin{tabular}{|c|c|c|c|c|}
\hline Topic ${ }^{b}$ & No mention & $\begin{array}{c}\text { Addressed } \\
\text { in some way }\end{array}$ & Refuge concern & $\begin{array}{l}\text { Refuge concern } \\
\text { and prescription }\end{array}$ \\
\hline \multicolumn{5}{|l|}{ Common } \\
\hline Habitat & 0.5 & 99.5 & 99.5 & 98.9 \\
\hline Invasive species & 1.1 & 98.9 & 96.2 & 93.5 \\
\hline Game species & 0.0 & 100.0 & 97.3 & 95.7 \\
\hline Federally listed species ${ }^{c}$ & 1.2 & 98.8 & 92.7 & 89.7 \\
\hline Nongame species & 2.2 & 97.8 & 93.5 & 93.5 \\
\hline \multicolumn{5}{|l|}{ Specialized } \\
\hline \multicolumn{5}{|l|}{ Landscape conservation } \\
\hline Fire regime & 33.0 & 67.0 & 55.7 & 54.1 \\
\hline Aquatic connectivity & 31.9 & 68.1 & 57.8 & 54.1 \\
\hline Terrestrial connectivity & 22.7 & 77.3 & 60.5 & 49.2 \\
\hline Landscape other & 53.0 & 47.0 & 39.5 & 34.6 \\
\hline \multicolumn{5}{|l|}{ Climate change } \\
\hline Habitat & 45.9 & 54.1 & 1 & 31.9 \\
\hline Sea-level rise & 58.4 & 41.6 & 31.9 & 19.5 \\
\hline Wildlife & 56.8 & 43.2 & 32.4 & 18.4 \\
\hline Freshwater availability & 61.1 & 38.9 & 24.9 & 13.5 \\
\hline Fish & 73.0 & 27.0 & 17.8 & 11.4 \\
\hline Undesirable species & 76.8 & 23.2 & 14.1 & 9.2 \\
\hline Extreme weather & 65.4 & 34.6 & 22.7 & $8.6^{d}$ \\
\hline Fire frequency $\&$ intensity & 83.2 & 16.8 & 10.8 & $5.4^{d}$ \\
\hline Disease/parasites & 85.4 & 14.6 & 7.0 & $3.2^{d}$ \\
\hline \multicolumn{5}{|l|}{ Environmental quality } \\
\hline Water quality & 4.3 & & 89.7 & 77.8 \\
\hline Water quantity & 33.5 & 66.5 & 54.6 & 47.6 \\
\hline Noise pollution & 67.0 & 33.0 & 20.5 & 10.3 \\
\hline Air quality & 30.3 & 69.7 & 25.4 & $9.7^{d}$ \\
\hline
\end{tabular}

${ }^{a}$ Sample size 185 CCPs, except for federally listed species, which were limited to refuges known or suspected of having listed species, $n=165$.

${ }^{b}$ Within categories, topics are ordered by proportion of CCPs with prescriptions from highest to lowest.

${ }^{c}$ Conservation status data for federally listed species are calculated only for CCPs that report at least occasional refuge use by federally listed species. In addition to these, one refuge that has no endangered species is determining suitability for one such species that occurs in the region.

${ }^{d}$ The majority of CCPs with refuge concerns for this topic lack prescriptions for it.

Table 3. Changes over time in proportion of comprehensive conservation plans with prescriptions that address specialized conservation topics.

\begin{tabular}{|c|c|c|c|c|c|c|c|}
\hline Topic & 2005 & 2006 & 2007 & 2008 & 2009 & 2010 & 2011 \\
\hline \multicolumn{8}{|l|}{ Landscape conservation } \\
\hline Fire regime & 56 & 51 & 64 & 39 & 44 & 79 & 45 \\
\hline Aquatic connectivity & 38 & 51 & 52 & 35 & 59 & 66 & 80 \\
\hline Terrestrial connectivity & 38 & 41 & 60 & 39 & 52 & 59 & 60 \\
\hline Landscape other & 44 & 19 & 48 & 19 & 37 & 48 & 40 \\
\hline \multicolumn{8}{|l|}{ Climate-change threat } \\
\hline Habitat or plant community & 6 & 5 & 8 & 29 & 48 & 69 & 60 \\
\hline Sea-level rise & 0 & 0 & 16 & 26 & 19 & 41 & 35 \\
\hline Wildlife & 6 & 0 & 4 & 16 & 33 & 45 & 25 \\
\hline Freshwater availability & 6 & 0 & 0 & 6 & 26 & 28 & 35 \\
\hline Fish & 6 & 0 & 0 & 6 & 15 & 31 & 25 \\
\hline Undesirable species & 0 & 0 & 4 & 3 & 11 & 28 & 20 \\
\hline Extreme weather & 6 & 0 & 0 & 3 & 26 & 21 & 5 \\
\hline Fire frequency $\&$ intensity & 0 & 0 & 0 & 3 & 11 & 17 & 5 \\
\hline Disease \& parasites & 0 & 0 & 0 & 3 & 0 & 17 & 0 \\
\hline \multicolumn{8}{|l|}{ Environmental quality } \\
\hline Water quality & 69 & 78 & 76 & 61 & 85 & 90 & 85 \\
\hline Water quantity & 19 & 41 & 56 & 39 & 44 & 69 & 60 \\
\hline Air quality & 6 & 8 & 16 & 10 & 7 & 14 & 5 \\
\hline Noise pollution & 6 & 11 & 16 & 16 & 11 & 7 & 0 \\
\hline Total CCPs & 16 & 37 & 25 & 31 & 27 & 29 & 20 \\
\hline
\end{tabular}


Table 4. Proportions of comprehensive conservation plans that address common and specialized conservation topics through various management approaches and aspects of adaptive management. ${ }^{a}$

\begin{tabular}{|c|c|c|c|c|c|c|c|c|}
\hline \multirow[b]{2}{*}{ Topic } & \multicolumn{4}{|c|}{ Management approaches } & \multicolumn{4}{|c|}{ Aspects of adaptive management } \\
\hline & Action & $\begin{array}{l}\text { Plan or } \\
\text { study }\end{array}$ & Model $^{b}$ & $\begin{array}{c}\text { Action outside } \\
\text { refuge }\end{array}$ & Monitor & $\begin{array}{c}\text { Specific actions } \\
\text { linked to monitoring }\end{array}$ & $\begin{array}{c}\text { Qualitative } \\
\text { target }\end{array}$ & $\begin{array}{c}\text { Quantitative } \\
\text { target }\end{array}$ \\
\hline \multicolumn{9}{|l|}{ Common } \\
\hline Habitat & 91.4 & 78.4 & 40.5 & 39.5 & 90.3 & 37.3 & 9.2 & 46.5 \\
\hline Invasive species & 84.9 & 64.3 & 26.5 & 26.5 & 85.9 & 41.6 & 18.4 & 34.1 \\
\hline Federally listed species & 75.2 & 49.7 & 16.4 & 25.5 & 84.8 & 26.1 & 13.3 & 18.2 \\
\hline Nongame species & 70.8 & 61.6 & 21.1 & 14.6 & 88.1 & 17.8 & 11.4 & 13.5 \\
\hline Game species & 74.6 & 64.9 & 13.0 & 16.2 & 83.8 & 21.6 & 9.2 & 20.5 \\
\hline \multicolumn{9}{|l|}{ Specialized } \\
\hline Landscape ecology & 76.8 & 51.4 & 24.9 & 31.9 & 56.2 & 20.5 & 8.6 & 20.5 \\
\hline Climate change & 11.9 & 22.7 & 13.0 & 4.9 & 30.3 & 4.9 & 1.1 & 1.6 \\
\hline Environmental quality & 61.6 & 43.8 & 16.8 & 36.8 & 69.2 & 14.1 & 9.2 & 8.1 \\
\hline
\end{tabular}

${ }^{a}$ Sample size 185 CCPs, except for federally listed species, which were limited to refuges known or suspected of having listed species, $n=165$.

${ }^{b}$ A plan was scored as using modeling if a model (including GIS models) was constructed or an existing model was used to support decision making or setting management targets.

development occurred in $68 \%$ of CCPs, but prescriptions responding to that threat occurred in only $29 \%$ of them.

Actions were the most frequent management approaches in prescriptions for common conservation issues, followed by plans and studies (Table 4). The most common types of plan or study were "step-down" plans (e.g., habitat management plans). The 172 CCPs anticipating future step-down plans listed an average of 7.4 such plans. Modeling (commonly GIS applications and the sea-level-rise model SLAMM (Craft et al. 2009)) and actions outside the refuge were always used less often than planning and acting inside the refuge.

Distribution of management approaches for specialized topics was similar to the distribution for common issues. Climate change was the only one of 8 topics for which plans and studies occurred in prescriptions more frequently than direct actions (Table 4).

\section{Planning to Act Outside the Refuge Boundary}

Overall, 68\% of CCPs contained at least one prescription for action outside a refuge. Among the 5 common conservation issues, actions outside refuges were used most often to address habitat concerns, followed by invasive species and federally listed species (Table 4). More than $30 \%$ of CCPs recommended acting outside the refuge for landscape conservation and environmental quality. On average, CCPs prescribing outside actions did so for 3.0 of the 8 topics. The overall proportion of CCPs with prescriptions for acting outside refuges declined from 2010 to 2011 , from $72 \%$ to $60 \%$.

Among CCPs scoring highest for overall use of actions outside refuges, prescriptions for acting outside fell into 5 categories: abating specific threats and participating in state or local planning, assisting neighboring landowners to conserve habitat on their lands, partnering with other organizations, wildlife management, and invasive species control (Table 5). However, even among these examples, most failed to meet FWS' SMART criteria (Adamcik et al. 2004).

\section{Adaptive Management in CCP Prescriptions}

Monitoring was the most common element of adaptive management in prescriptions that addressed the conservation issues we explored (Table 4). It appeared in all but one CCP. An average of 5.8 of 8 topics in each CCP used monitoring. Specific actions to follow from monitoring results appeared in 61\% of CCPs; those that indicated specific actions did so for 2.6 topics. But overall, 96\% of CCPs with prescriptions for monitoring failed to indicate specific actions to follow from one or more of the monitoring prescriptions. The average number of topics addressed by prescriptions for monitoring increased from 2007 to 2010 and declined, along with specific actions to follow from monitoring, from 2010 to 2011.

The CCPs rarely used the language of hypothesis testing when describing planned studies and actions. Nine CCPs discussed the need to develop and test hypotheses in order to fully implement adaptive management. Only one CCP described a prescription as representing a hypothesis.

Among common topics, more than half of habitatmanagement and invasive-species prescriptions (62\% and $61 \%$, respectively) used qualitative or quantitative monitoring targets. In contrast, less than half of prescriptions for federally listed, game, and nongame species included targets $(37 \%, 35 \%$, and 29\%, respectively). When targets were present, they were more often quantitative than qualitative, for all topics (Table 4). Even when they were quantitative, monitoring targets did not always correspond to ultimate aims. For instance, the Merritt Island CCP included a target of habitat for 


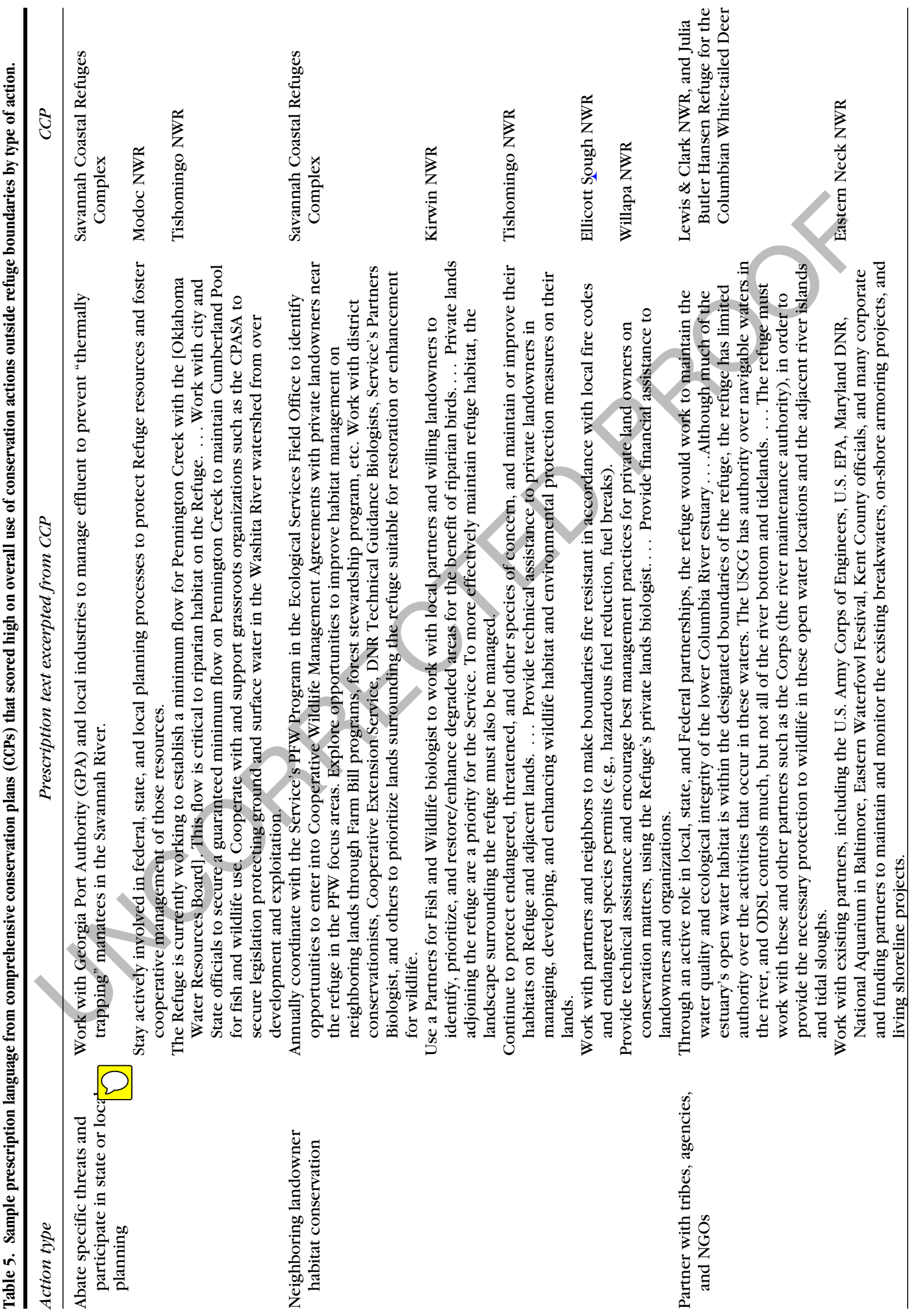




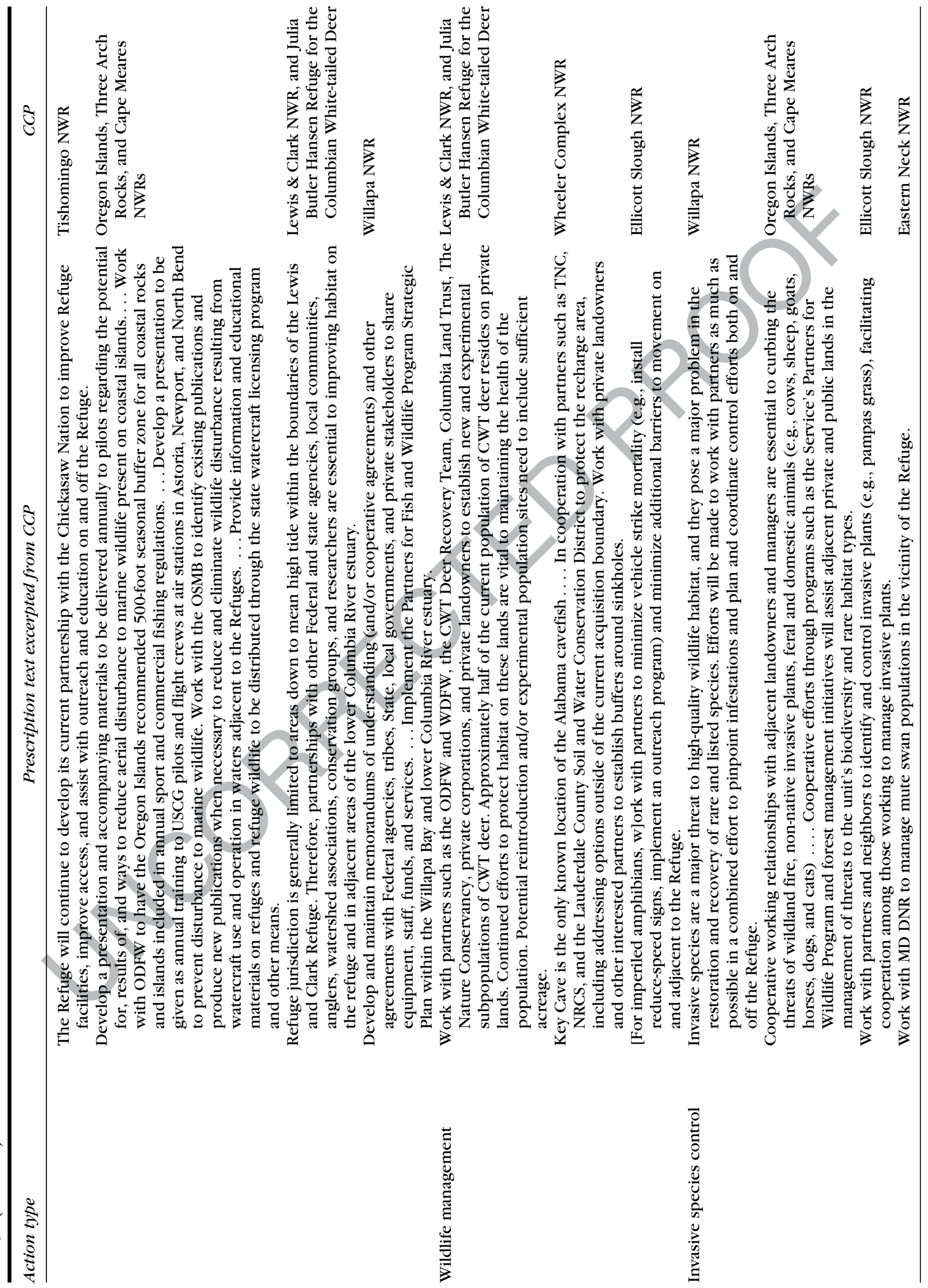


Table 6. Degree of integration of major landscape conservation plans and programs into comprehensive conservation plans (CCPs) shown as a proportion of CCPs examined. ${ }^{a}$

\begin{tabular}{lcccc}
\hline & No mention & $\begin{array}{c}\text { Mention, citation, } \\
\text { or description }\end{array}$ & $\begin{array}{c}\text { Refuge context } \\
\text { noted }\end{array}$ & $\begin{array}{c}\text { Used to justify } \\
\text { prescription }\end{array}$ \\
\hline Forest Legacy Program & 96.2 & 2.7 & 0.5 & 0.5 \\
Federal land-use plans & 95.7 & 2.7 & 1.1 & 7.6 \\
Landscape Conservation Cooperative & 88.1 & 3.2 & 0.6 & 0.5 \\
Habitat conservation plans & 96.4 & 1.9 & 26.5 & 1.1 \\
North American Bird Conservation Initiative & 4.3 & 9.2 & 10.9 & 1.2 \\
Recovery plans & 30.3 & 12.1 & 18.4 & 46.0 \\
State wildlife action plans & 38.9 & 20.0 & 5.4 & 22.7 \\
Farm Bill programs & 68.1 & 14.6 & 11.9 \\
\hline
\end{tabular}

${ }^{a}$ Sample size 185, except recovery plans and habitat conservation plans scored only in CCPs that include a refuge at least occasionally used by federally listed species for which $n=165$.

250 mottled ducks (Anas fulvigula), but monitoring was limited to confirming habitat availability. No monitoring addressed numbers of mottled ducks.

Among the specialized topics, all adaptive management elements were less frequently used in climate-change prescriptions compared with landscape-conservation or environmental-quality prescriptions (Table 4). Monitoring was used consistently less, overall, to address specialized topics than common topics.

\section{Integration of Other Plans and Programs into CCPs}

In addition to addressing external threats to refuge resources, CCPs can be coordinated with landscape conservation plans from other agencies and organizations to project conservation benefits beyond refuge boundaries. The plans most thoroughly integrated into the CCPs were associated with North American Bird Conservation Initiative programs (NABCI) (e.g., Partners in Flight). Sixty percent of CCPs used NABCI plans to justify CCP objectives (Table 6). This is consistent with the proportion (59\%) of CCPs established, in part, under the Migratory Bird Conservation Act. Among plans related to threatened and endangered species, recovery plans were well integrated, but habitat conservation plans almost never were.

Farm Bill programs such as the Conservation and Wetland Reserve Programs were mentioned in 32\% of CCPs overall (Table 6), but regional variation was considerable. Even in the $4 \mathrm{FWS}$ regions encompassing the central agricultural belt, only $40-56 \%$ of CCPs mentioned Farm Bill programs; only 11-29\% justified goals and objectives on the basis of these programs; elsewhere, mention and use of these programs was even lower.

Many SWAPs were not completed until 2005. Of CCPs completed in 2006 , only $22 \%$ mentioned the plans at all. However, by 2010, $>70 \%$ of CCPs either discussed how the refuge fit into the context of state plans or used a state plan to justify CCP prescriptions (this proportion dropped to $60 \%$ in 2011). Similarly, references to the Landscape Conservation Cooperatives (LCCs) began to appear in CCPs produced in 2009, the year in which the LCCs were announced, and rose consistently thereafter.
Integration of NABCI plans and recovery plans also increased over the period of study, but less dramatically. However, CCPs rarely mentioned conservation plans of other federal public land units or the Forest Legacy pro$\operatorname{gram}(<5 \%)$.

\section{Cross-Cutting Relationships}

Strong integration of regional land-use plans tended to co-occur with high use of acting outside the refuge and of adaptive management. The number of topics, out of 8 , for which CCPs used actions outside the refuge was significantly correlated to both number of topics for which monitoring was prescribed $\left(r_{s}=0.283, n=185, p<\right.$ 0.001 ) and number of topics for which prescriptions included specific actions to follow from monitoring $\left(r_{s}=\right.$ $0.237, n=185, p=0.001$ ).

The level of integration (scored from "no mention" to "used to justify prescriptions") of Farm Bill programs, which are largely applied outside the refuges, was significantly correlated with overall use of actions outside the refuge $\left(r_{s}=0.218, n=185, p=0.003\right)$. Plans that used monitoring for more conservation topics also tended to integrate SWAPs and NABCI plans well $\left(r_{s}=0.178\right.$, $p=0.015 ; r_{s}=0.206, p=0.005 ; n=185$ ). All correlation coefficients presented in this section were relatively small, indicating weak predictive ability. Strength in one planning area was not a strong guarantee of strength in other areas.

CCPs that covered refuges created at least in part under the U.S. Endangered Species Act had higher use of actions outside the refuge than CCPs that lacked such refuges ( 2.40 vs. 1.77 topics out of 8 addressed using actions outside the refuge; $t=-2.03$, df $=183, p=0.044$ ). CCPs created, at least in part, under the U.S. Emergency Wetland Act and the Wilderness Act showed no such relationships (both $p \geq 0.16$ ).

\section{Discussion}

The CCPs we studied apply to a staggeringly diverse array of protected areas. In addition to large, named national 
wildlife refuges, CCPs also cover thousands of easements, many gathered into wetland management districts. The refuges covered in our study represent a hodgepodge of locations, establishment purposes, sizes, and visitor uses. In this respect, the studied CCPs are characteristic of the refuge system as a whole (Fischman 2003) and represent diverse circumstances that have analogies to many other conservation reserves, both public and private.

\section{Management Issues and Prescriptions}

Most CCPs contained sprawling descriptions of biological resources and recreational opportunities of their refuges. However, goals, objectives, and implementation strategies, not descriptions, composed the core content of each CCP: the prescriptive sections are the engines that generate real management actions. The CCPs did a much better job describing and documenting resources and environment of refuges than they did developing prescriptions that responded to important threats, the key needs of adaptive management, and FWS' SMART guidelines (Adamcik et al. 2004). Because most secondgeneration CCPs will not need extensive revisions to environmental descriptions, we suggest a focus on improving prescriptions and landscape-level connections.

If a CCP describes an issue as a regional or refuge concern, the nature of the document suggests it will be matched with prescriptive language that addresses the threat. The common conservation topics we studied were addressed by prescriptions in $\geq 90 \%$ of CCPs, but the 3 specialized topics were less often addressed with prescriptions. These topics-landscape-scale conservation (including issues of connectivity, patch size, and ecosystem processes), climate change, and environmental quality-were likely under-reported as refuge concerns (Scott et al. 2004; Meretsky et al. 2006). Underreporting explained at least some of the associated lack of prescriptions. However, for several topics-especially agricultural and development impacts and particularly for most climate-change impacts-CCPs reporting refuge concerns seldom contained responsive prescriptions (Table 2).

The trend of increasing proportions of CCPs addressing aquatic connectivity is a promising signal of improving landscape-scale conservation, particularly as a means of addressing climate-change stress. The next generation of CCPs should extend the trend to other landscape conservation issues. Among environmental quality concerns, high levels of prescriptions for water-quality issues and the increasing trend in prescriptions for water quantity offer models for future improvements. Overall, these results reflected a strong foundation for building better landscape-level prescriptions that address the entire range of water issues. Even with this strong beginning, however, quantitative targets were surprisingly sparse for water quality, given the number of numerical standards set by regulatory agencies.

Explicit prioritization of refuge goals appeared in $17.3 \%$ of CCPs. In some cases, the CCP provided more subtle clues to refuge priorities, but not clearly. A primary function of conservation plans is to prioritize use of management resources in light of resource limitations (Knight et al. 2011; Game et al. 2013). It is true that refuge managers often deal with funding streams and other opportunities that are independent of CCP priorities. But well-reasoned priorities help refuge staff maintain focus and provide an impetus to match actions with priorities whenever possible.

The CCPs commonly deferred decisions to future plans or studies. Step-down plans are useful, but only if CCP prescriptions set clear benchmarks for objectives (i.e., through SMART criteria) and only if FWS can actually deliver the promised plans (an average of $>7$ per CCP over a 15-year term). A recent survey of refuge employees showed employees believed step-down plans were important, but they also suggested that limited funds and planning capacity reduced the likelihood of completing step-down plans in a timely manner (USFWS 2013). Although we agree with FWS policy that calls for stepdown plans "to provide strategies and implementation schedules" for meeting CCPS objectives, step-down plans can serve those functions best if overarching plans contain specific objectives (602 FW 4). The relative scarcity of environmental impact statements (EISs) accompanying CCPs may make step-down planning more timeconsuming than currently anticipated. Also, deferring key decisions reduces incentives for interested stakeholders to participate in plan development (Knight et al. 2011). A new task facing second-generation CCPs will be to integrate the myriad step-down plans that are prepared under the existing CCPs.

\section{Adaptive Management}

Like most conservation planners, FWS states an intention to employ adaptive management to grapple with uncertainty and to learn by doing (602 FW 3). Although CCPs often indicated a need to monitor management outcomes and adjust management actions if needed to meet goals, only one plan used the term bypothesis in describing a prescription. A handful of others indicated a need to develop such hypotheses in the future.

In practice, adaptive management conducted by natural resource agencies consists of monitoring and changing course in the face of failure (USDOI 2009) rather than treating management activities as experiments involving testable hypotheses in which data provide welldocumented lessons from successes and failures. The former practice is less effective than fully implemented adaptive management, but more practical in the face of austerity. In its most extreme form, this open-ended 
contingency planning or "on-the-fly" management that promises some loosely described response to whatever circumstances arise has been characterized as "AM-lite" (Ruhl \& Fischman 2010). At its best, some monitoring and changing course in the face of failure is a passive form of adaptive management, suitable to circumstances where the ranges of possible variations in actions and outcomes are small (Gregory et al. 2006). But AM-lite may also be a pretext for postponing difficult, but important, decisions in order to dodge constraints of budgets, politics, or scientific uncertainty (Ruhl \& Fischman 2010). The FWS' SMART criteria for evaluating prescriptions (Adamcik et al. 2004) match the requirements of good adaptive management. But CCPs and other conservation plans generally fall far short of meeting the SMART criteria (Schroeder 2008). In 2013, the implementation team for FWS' strategic vision recommended that revised CCPs adopt a broad scope and leave more details for step-down planning (USFWS 2013). Some details, especially descriptive ones, are not necessary in CCPs. But without specific, measurable, achievable, results-oriented, and time-fixed criteria, those who monitor and change tactics with failure can drift along without learning or attaining plan goals.

Monitoring is a necessary but not sufficient foundation for adaptive management approaches, and CCPs excelled at including this management approach in prescriptions. But CCPs prescribed monitoring of many indicators and seldom stated priorities. When appropriate, CCPs should strive to employ common, standard monitoring protocols to facilitate coordination of conservation efforts across regions (Meretsky et al. 2012). Not all refuge information needs can be met by such protocols, but many can.

CCPs commonly called for monitoring but did not discuss how management should respond to monitoring results. More than half of CCPs contained at least one prescription that indicated a specific action to result from monitoring. But, issue by issue, less than half (often much less than half) of CCPs that prescribed monitoring for a particular issue described specific actions that might result from such monitoring (Table 4). Failure to connect monitoring with management consequences will hinder success even with passive adaptive management.

The next round of CCPs should strive to eliminate monitoring dead ends by defining quantitative triggers for acting in response to monitoring (Nie \& Schultz 2012). Our results show plenty of room for improvement, especially for water-quality prescriptions, where numerical standards are widely available and refuges have welltested options for effecting improvements, such as riparian buffers. Similarly, there is ample room for improving quantitative triggers for federally listed species and for targets established by SWAPs.

Our results suggest that plans that define specific actions to follow from monitoring tend to contain more prescriptions that address actions outside the refuge boundary. These relationships in our data indicate that thinking through adaptive management approaches may lead to greater awareness of external actions and outside program or plan integration needed to achieve landscape conservation goals.

\section{External Threats}

The FWS has done better than other U.S. land-managing agencies in developing management prescriptions that include substantive actions outside of refuge boundaries. It was the first to have a policy requiring such actions, and only the Forest Service has since explicitly addressed landscape-scale efforts in its planning requirements (36 C.F.R. 219.7(f)(1) \& 219.8(a)(2)). We believe our results reflect the relatively strong provision of FWS' ecological integrity policy encouraging managers to address external threats (601 FW 3.20); 68\% of CCPs we studied contain prescriptions for actions outside of a refuge. Moreover, refuge managers may be planning for and taking external actions that they are not noting as such in CCPs. For example, use of Farm-Bill programs to provide wildlife habitat off-refuge seems underdocumented as an off-refuge action.

Public land managers are cautious about planning to act outside their land boundaries because neighboring private landowners and local governments may take umbrage at the exercise of federal power. However, given FWS' strategic aims (USFWS 2011), there remains room for improving the number and content of these actions. One helpful approach might be better sharing (among refuges and between refuges and partners) of effective tools and methods for acting outside the refuge. In reviewing the 2005-2011 CCPs, we identified work with Farm Bill programs-particularly methods for recruiting neighbors to enroll and for optimizing conservation results-as an unevenly applied approach. Some of the more successful applications offer lessons that could usefully be shared throughout the refuge system. In addition, FWS could better share actual CCP provisions that address specific problem types (e.g., water-quality degradation upstream) through actions outside the refuge. Table 5 provides examples and a framework for organizing them that may serve as a starting point for best-practices sharing. Other U.S. land management agencies, such as the Forest Service, with its "all-lands" approach to planning (77 Fed. Reg. 21162, 2012), and the National Park Service, with its own strong policy mandate for addressing external threats (NPS 2006, \$1.6), would benefit from wider sharing of the tools illustrated in Table 5.

Land-use threats deserve more attention in prescriptions that look outside refuge boundaries. Of the refuges we studied, $81 \%$ had adjacent rural land uses, and 36\% had suburban neighbors. These and other landscape types associated with potential and existing development can create external sources of impairment to refuge resources 
(Meretsky et al. 2006). Although 68\% of CCPs discussed threats from future development, only $29 \%$ contained prescriptions responding to those threats. By the time climate change poses serious risks to many refuge resources, resilience strategies such as connecting corridors and protective buffers may be precluded through increased housing development around and between many refuge units in the eastern United States and southern United States. Securing corridors and buffers today may preempt external threats in the future and build greater landscape-level ecological integrity (Galatowitsch et al. 2009; Hamilton et al. 2013).

The CCP revisions should take advantage of more landscape-scale conservation opportunities to address the ultimate, off-refuge cause of problems currently addressed on refuges. Tracing the causal chain may point to policies and practices that refuge managers can affect, perhaps in partnership with existing coalitions (Salafsky et al. 2002). Examples might include invasive species regulations, watershed management, or zoning. Prioritizing the off-refuge issues with the strongest links to the most important refuge problems would be one way to begin.

\section{Regional Conservation Programs}

Refuge context is important beyond the local need for abating external threats. The refuges constitute a system that aims to project environmental benefits beyond unit boundaries to contribute to landscape-scale conseryation objectives (Fischman 2003; USFWS 2011). Such an undertaking requires coordination with other, nonrefuge conservation efforts. Our results show substantial and effective use of the NABCI programs, likely due to the large variety and number of NABCI tools available to conserve bird species. The NABCI programs also dovetail with the traditional waterfowl focus of many refuge units and the predominance of migratory-bird-related establishment authorities. For refuges containing federally listed species, CCPs also substantially and effectively integrate ESA recovery plans. Refuges seeking to recover imperiled species generally need to coordinate with other stakeholders who manage habitat and activities that threaten the species. Like many bird species, listed species are a focus for management for many entities outside refuges, and the recovery plans provide a hub for coordination to enhance landscape-scale conservation of these species.

Still, plenty of room for improvement exists for CCPs to better engage with regional conservation plans and programs. In the opinion of one FWS planner, the CCPs should begin to focus as much attention on regional "stepup" plans, to integrate landscape-scale goals, as it does on "step-down" management plans. In 2013, the implementation team for FWS' strategic vision recommended just such integration in the upcoming revisions to the CCPs (USFWS 2013). A new category of planning documents, landscape conservation designs, would be developed by regional partnerships facilitated by the LCCs. Landscape conservation designs would precede CCP revisions and tie refuges within a region to many landscape-level programs. Many plans, especially SWAPs, have the potential to contribute more to the refuge system mission. If FWS can maintain the 2005-2010 trend of increased SWAP integration, through landscape conservation designs and other methods, nongame species conservation and other statewide concerns may begin to have the degree of management engagement provided under NABCI.

Farm Bill programs offer refuges powerful, underutilized (or at least under-reported) tools for projecting conservation benefits beyond refuge boundaries, as well as for addressing water quality and other external threats. The integration of Farm Bill programs into CCP prescriptions correlates with use of actions outside the refuge in our study, suggesting that outward-looking CCPs make better use of these programs. But the average degree of integration of Farm Bill programs in CCPs was quite low (Table 6). Particularly in the farm belt areas, CCPs should better integrate these tools, or, if they are already using them (as we suspect), their use should be better documented in CCPs.

\section{Documenting Environmental Impacts}

Unlike unit-level planning for other federal public land systems, the CCP process does not require preparation of an EIS under the U.S. National Environmental Policy Act (NEPA; Fischman 2003). Instead, FWS makes a caseby-case determination of whether a planning effort is a "major federal action significantly affecting the quality of the human environment" (emphasis added) ( 42 U.S.C. $\int$ 4332). The rule defining significantly instructs agencies to consider both the context and the intensity of a proposed action (40 C.F.R. $\ 1508.27$ ). Many of the management regimes promoted by CCPs do not involve severe environmental impacts. But the setting of a refuge, a unit within the largest conservation system dedicated to wildlife protection, and the ecologically critical areas involved would seem to meet the significance threshold for a CCP based on context. Nonetheless, FWS prepared EISs for only 21 of the 185 CCPs in our study.

The FWS refuge planning policy requires EISs only for those CCPs recommending wilderness designation (602 FW 3.4C(1)(c)). Many CCPs grappling with controversial issues, such as whether livestock grazing should continue, also prepare EISs, probably in defensive anticipation of litigation (e.g., U.S. District Court 2007). The prevalence of environmental assessments suggests a lack of confidence in planning to make a substantial environmental impact and in the importance of refuges (compared with other federal conservation systems) to the broader national conservation agenda. It also reflects austere budgets for FWS. 
The heavy reliance on future step-down plans to implement CCP prescriptions makes the use of environmental assessments for CCPs particularly problematic. The rules implementing NEPA allow agencies to tier environmental analyses of step-down plans to EISs (40 C.F.R. \1508.28). The subsequent analysis may incorporate by reference the broader discussions and concentrate solely on more detailed issues. Without a broad CCP EIS to anchor tiering, refuges may find that substantive decisions of stepdown plans require more environmental impact analysis. This could slow the already ambitious schedule of stepdown plans. Other federal land management agencies commonly tier their equivalent of step-down plans to unit-level plan EISs. Tiering is also a very helpful tool for integrating adaptive management into the framework of NEPA and administrative law because it allows for rapid adjustment of actions in response to monitoring (Ruhl \& Fischman 2010). CCPs that fail to establish clear criteria for judging the success of management actions or to provide a foundation for easy NEPA tiering fall short of their potential efficacy.

\section{The 2011 Dip}

The CCPs completed in the final year of our study, 2011, displayed a reversal of several otherwise improving trends in climate-change prescriptions (Table 3 ) and in the degree of integration of recovery plans and SWAPs. The overall use of monitoring, specific actions, and actions outside the refuge dropped from 2010 to 2011. Also, but less dramatically, the proportions of CCPs with prescriptions addressing each of the 4 environmental quality issues declined in 2011. As the 2012 congressional deadline for completing first-round CCPs approached, haste may have diminished CCP quality. Because the newest CCPs may not necessarily be the best, FWS should resist prioritizing CCP revisions based solely on age of the original CCP.

\section{Acknowledgments}

The FWS (especially R. Alliston and T. Larson) and R. Schroeder provided help in research and analysis. A. Hausman, S. Seller, K. Mantsch, and R. Weiss provided research assistance. Our Spring 2012 Indiana University capstone class assisted in coding plans and interpreting data.

\section{Literature Cited}

Adamcik, R. S., E. S. Bellantoni, D. C. DeLong Jr., J. H. Schomaker, D. B. Hamilton, M. K. Laubhan, and R. L. Schroeder. 2004. Writing refuge management goals and objectives: a handbook. US Fish and Wildlife Service, Washington, D.C. Available from http://library.
fws.gov/Refuges/WritingRefugeGoals_022504.pdf (accessed February 26,2013$)$.

Bottrill, M. C., and R. L. Pressey. 2012. The effectiveness and evaluation of conservation planning. Conservation Letters 5:407-420.

Craft C., J. Clough, J. Ehman, S. Joye, R. Park, S. Pennings, H. Guo, and M. Machmuller. 2009. Forecasting the effects of accelerated sea-level rise on tidal marsh ecosystem services. Frontiers in Ecology and the Environment 7:73-78.

Fischman, R. L. 2003. The national wildlife refuges: coordinating a conservation system through law. Island Press, Washington, D.C.

Galatowitsch, S., L. Frelich, and L. Phillips-Mao. 2009. Regional climate change adaptation strategies for biodiversity conservation in a midcontinental region of North America. Biological Conservation 142:2012-2022.

Game, E. T., P. Kareiva, and H. P. Possingham. 2013. Six common mistakes in conservation priority setting. Conservation Biology DӨI: 10.1111/cobi.12051.

Gregory, R., L. Failing, and P. Higgins. 2006. Adaptive management and environmental decision making: a case study application to water use planning. Ecological Economics 58:434-447.

Hamilton, C. M., S. Martinuzzi, A. J. Plantinga, V. C. Radeloff, D. J. Lewis, W. E. Thogmartin, P. J. Heglund, and M. A. Pidgeon. 2013. Current and future land use around a nationwide protected area network. PLOS ONE 8(1) DOI:10.1371/journal.pone.0055737.

Hilty, J. A., and C. R. Groves. 2009. Conservation planning: new tools and new approaches. Pages 105-120 in R. L. Knight and C. White, editors. Conservation for a new generation: redefining natural resources management. Island Press, Washington, D.C.

Knight, A. T., R. M. Cowling, A. F. Boshoff, S. L. Wilson, and S. M. Pierce. 2011. Walking in STEP: Lessons from linking spatial prioritisations to implementation strategies. Biological Conservation 144:202211.

Loomis, J. B. 2002. Integrated public lands management. Columbia University Press, New York

Meretsky, V. J., R. L. Fischman, J. R. Karr, D. M. Ashe, J. M. Scott, R. F. Noss, and R. L. Schroeder. 2006. New directions in conservation for the national wildlife refuge system. BioScience 56:135-143.

Meretsky, V. J., et al. 2012. A state-based national network for effective wildlife conservation. BioScience 62:970-976.

Nie, M., and C. Schultz. 2012. Decision-making triggers in adaptive management. Conservation Biology 26:1137-1144.

NPS (National Park Service), U.S. Department of the Interior. 2006. Management policies. Available from http://www.nps.gov/ policy/mp/policies.html (accessed September 2013).

Ruhl, J. B., and R. L. Fischman. 2010. Adaptive management in the courts. University of Minnesota Law Review 95:424-484.

Salafsky, N. R., R. Margoluis, K. H. Redford, and J. G. Robinson. 2002. Improving the practice of conservation: a conceptual framework and research agenda for conservation science. Conservation Biology 16:1469-1479.

Schroeder, R. L. 2008. Comprehensive conservation planning and ecological sustainability within the United States national wildlife refuge system. Sustainability: Science, Practice \& Policy 4:1-7.

Schomaker, J. H. 2009. National wildlife refuge managers' evaluation of comprehensive conservation plans: repert. Repert to the US Fish and Wildlife Service, National Planning Workshop, Shepherdstown, VA.

Scott, J. M., T. Loveland, K. Gergely, J. Strittholt, and N. Staus. 2004 National wildlife refuge system: ecological context and integrity. Natural Resources Journal 44:1041-1066.

USDOI (U.S. Department of the Interior). 2009. Adaptive management: the U.S. Department of the Interior technical guide. Revised edition. (B. K. Williams, R. C. Szaro, and C. D. Shapiro) USDOI, Washington, D.C. Available from http://www.doi.gov/ppa/upload/TechGuideWebOptimized-2.pdf (accessed September 2013).

U.S. District Court. 2007. Stevens County v. U.S. Department of the Interior, 507 F. Supp.2d 1127 (E.D. Wash.). 
USFWS (U.S. Fish and Wildlife Service). 2011. Conserving the future: wildlife refuges and the next generation. USFWS, Washington, D.C. Available from http://americaswildlife.org/wpcontent/uploads/2011/10/Final-Vision-Document.pdf (accessed February 26, 2013).
USFWS (U.S. Fish and Wildlife Service). 2013. Planning Implementation Team, Final report: a landscape-scale approach to refuge system planning. USFWS, Washington, D.C. Available from http://www.fws.gov/refuges/vision/pdfs/PlanningGuideRev10.pdf (accessed December 31, 2013). 


\section{Author Queries}

Q1: Author: A running head short title was not supplied; please check if this one is suitable and, if not, please supply a short title that can be used instead.

Q2: Author: "Quantitative targets included...." The meaning of this sentence is not clear; please rewrite or confirm that the sentence is correct.

Q3: Author: Please update reference Game et al. (2013) with volume no. and page range.

Q4: Author: Schomaker (2009) has not been cited in the text. Please indicate where it should be cited; or delete from the reference list. 